\title{
PEDAGOGIA MATERIALISTA HISTÓRICO-CRÍTICA: O CONTO LITERÁRIO COMO PROPOSTA DE ENSINO-APRENDIZAGEM DE LÍNGUA MATERNA
}

\author{
Valdeci Batista de Melo Oliveira ${ }^{1}$ \\ Francisco Pereira Smith Júnior ${ }^{2}$ \\ André Boniatti ${ }^{3}$ \\ Edina Boniatti ${ }^{4}$
}

\begin{abstract}
RESUMO
O presente artigo intenciona discutir e trazer à tona ideias para o desenvolvimento de uma pedagogia materialista histórico-crítica no âmbito das aulas de Língua Portuguesa, enfatizando questionamentos e atividades a ser desenvolvidos no Ensino Fundamental II principalmente, mas que podem ainda ser aplicados com variações em outras séries. Os textos escolhidos para análise e desenvolvimento de sequência didática foram $A$ festa no céu, conto tradicional do Brasil narrado por Luís Câmara Cascudo e A raposa e as uvas, uma das fábulas de Esopo. Pensamos assim contribuir com o ensino de língua portuguesa no Brasil e com o trabalho a partir de textos literários na América Latina, repercutindo as vozes de uma pedagogia voltada à humanização, ao pensamento crítico e à reflexão acerca da realidade que nos cerca. Para este estudo foram utilizados aportes teóricos de Labov (1997), Barthes (1976) e Fiorin (2008).
\end{abstract}

Palavras-chave: Ensino de Língua Portuguesa. Literatura. Ensino Fundamental.

\section{CRITICAL HISTORICAL MATERIALIST PEDAGOGY: THE SHORT STORY AS A TEACHING-LEARNING PROPOSAL FOR THE MOTHER TONGUE}

\begin{abstract}
${ }^{1}$ Doutora em Letras (Literatura Portuguesa) pela Universidade de São Paulo (2007). Docente da categoria associado professora associada do Curso de Letras da UNIOESTE - Universidade Estadual do Oeste do Paraná campus de Cascavel. Docente do Programa Profletras - Mestrado Profissional em Letras e do Programa de PósGraduação em Letras (PPGL) da Unioeste - Campus Cascavel - nível Mestrado e Doutorado.E-mail: valzinha.mello@hotmail.com Orcid: orcid.org/0000-0002-7623-4087.

${ }^{2}$ Doutor em Ciências pelo Núcleo de Altos Estudos Amazônicos (NAEA/UFPA) e realizando pós-doutoramento em Estudos Comparados (UNIOESTE). Professor associado I da Universidade Federal do Pará, UFPA. Professor do curso de Licenciatura integrada em Ciências, Matemática e Linguagens da Faculdade de Educação Matemática e Científica do Instituto de Educação Matemática e Científica (FEMCI/IEMCI) e do Programa de Pós-Graduação em Linguagens e Saberes na Amazônia (PPLSA/ UFPA). Coordenador do Grupo de pesquisa de Estudos de Letramento Literário e Formação Interdisciplinar (GELLIFI /UFPA). Coordenador do Grupo de Estudos de Literatura Comparada do Nordeste Paraense (GELCONPE/UFPA). fsmith@ufpa.br. Orcid: 00000002-6336-9249

${ }^{3}$ Mestre em Letras pela Universidade Estadual do Oeste do Paraná (2016). Doutorando na área de Letras Linguagem e Sociedade - com enfoque em Estudos Literários pela Universidade Estadual do Oeste do Paraná Programa de Pós-Graduação em letras (PPGL) - (2018-2022). Professor colaborador do Curso de Letras UNIOESTE-Cascavel. Doutorando do Programa de Pós-Graduação Institucional em Letras da UNIOESTECascavel, dramaturgo, escritor, desenhista. E-mail: zeforis@ hotmail.com. Orcid: orcid.org/0000-0003-22271613.

${ }^{4}$ Mestre em Letras pela Universidade Estadual do Oeste do Paraná (2007). Doutoranda na área de Letras Linguagem e Sociedade - com enfoque em Estudos Literários pela Universidade Estadual do Oeste do Paraná Programa de Pós-Graduação em letras (PPGL) - (2020-2024). Professora Quadro Próprio do Magistério do Estado do Paraná. E-mail: edina21boniatti@gmail.com. Orcid: orcid.org/0000-0003-3681-2951.
\end{abstract}


This article intends to discuss and bring up ideas for the development of a historical-critical materialist pedagogy within the Portuguese language classes, emphasizing questions and activities to be developed in Elementary School, but which can be applied with variations in other grades too. The texts chosen for analysis and development of the didactic sequence were A Festa no Céu (The party in the Sky), a traditional Brazilian tale narrated by Luís Câmara Cascudo andThe fox and the grapes, one of Aesop's fables. Thus we intend to contribute to the teaching of Portuguese language in Brazil and with the literature`s teaching in Latin American`s Elementary School, reflecting the voices of a pedagogy focused on humanization, critical thinking and reflection on the reality that surrounds us. For this study, we used the theoretical contributions of Labov (1997), Barthes (1976) e Fiorin (2008).

Keywords: Portuguese language teaching. Literature. Elementary School.

Data de submissão: 04.05.2021

Data de aprovação: 16.05 .2021

\title{
INTRODUÇÃO
}

\begin{abstract}
Um acontecimento ou uma situação vivida pelo entrevistado não pode ser transmitido a outrem sem que seja narrado. Isso significa que ele se constitui (no sentido de tornar-se algo) no momento mesmo da entrevista. Ao contar suas experiências, o entrevistado transforma aquilo que foi vivenciado em linguagem, selecionando e organizando os acontecimentos de acordo com determinado sentido. Esse trabalho da linguagem em cristalizar imagens que remetem a, e que significam novamente, a experiência é comum a todas as narrativas [...] (ALBERTI, 2003, p.1)
\end{abstract}

Ensinar e aprender a contar, a ler e a escrever textos narrativos no ensino fundamental pode ser atividade gratificante tanto para quem ensina, quanto para quem aprende. O elemento primordial que não pode faltar na consecução dessa atividade é a profunda relação havida entre a vida narrada no texto a ser lido e a vida factual vivida pelo aluno e pelo professor, pois narrar é viver duas vezes (uma no plano da realidade e outra no plano da interpretação da realidade, de sua memória, ou fantasia etc., enfim, no plano da contação, da narrativa). E todos nós humanos precisamos de mais vida, já que segundo Paulo Freire "a vocação ontológica do ser humano é ser mais”, e não menos (FREIRE, 2014, p. 19). Acrescente-se que todas as formas de vida neste planeta enfrentam muitos limites, percalços e lutas. A respeito disso, o poeta russo Maiakóvski lamenta a condição humana ao dizer de forma poética:

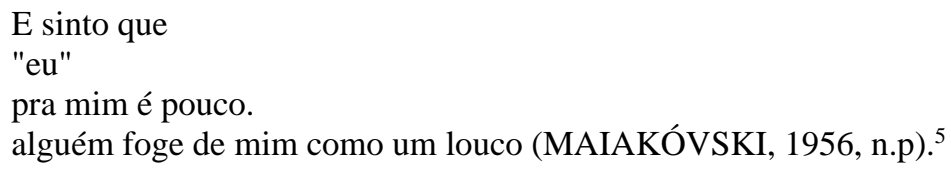

Outro poeta, o português Fernando Pessoa (2019), afirma: "A literatura, assim como a arte, é uma confissão de que a vida não basta.” (PESSOA, 2019) ${ }^{6}$ Para o humano que vive ou já viveu neste planeta, a vida basta ou já bastou? Na história da humanidade, desde os tempos das figuras nas cavernas rupestres, que podem ser lidas como uma confissão do desejo de continuidade e de ir, por meio da arte, além de si, percebemos que a vida - mesmo a desses homens primários - não basta, seja para o humano mais afortunado, para reis e rainhas, seja para os mais desgraçados.

\footnotetext{
${ }^{5}$ MAIAKOVSKI, Vladímir. Maiakovski. Antologia Poética. Trad. E. Carrera Guerra. Max Limonad, 1956.

${ }^{6}$ PESSOA, Fernando. Impermanence. In: Arquivo Pessoa. Disponível em: http://arquivopessoa.net/textos/3582. Acesso em: 03 out. 2019.
} 
Acerca disso, o poeta francês Alphonse de Lamartine, por sua parte, expressa no poema "L'Homme"7 as suas angústias a respeito da condição humana dizendo que:

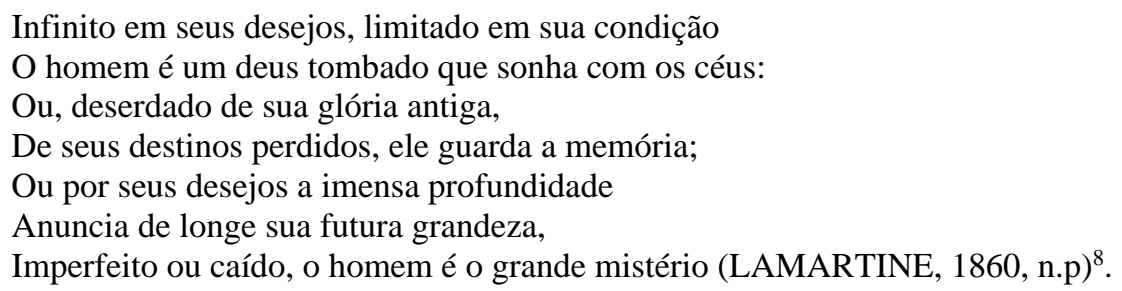

Nesse sentido, a narrativa é uma forma vicária de vida em cujo périplo os humanos dilatam o tempo de sua existência no mundo, vivendo - mediante ao relato das experiências das personagens - mais vidas, buscando "seus destinos perdidos", anunciando "sua futura grandeza", elaborando, por fim, projeções que tornem menos nebuloso o "grande mistério" que envolve a existência. Desse modo, a narração nos leva a viver ações e interações da vida mais de uma vez, pois segundo Fiorin (2008) "a narrativa é um simulacro da ação do homem no mundo", (FIORIN, 2008, p. 248). E se agimos no mundo, as mais das vezes, agimos em busca de algo que nos falta ou para proteger algo ou alguém valioso para nós, ou para nos livrarmos de algo que nos incomoda, ou de algum obstáculo que impede a realização da nossa vocação ontológica de ser mais. Tanto o contador/narrador quanto o ouvinte/leitor, ao ouvirem/lerem uma narrativa, tomam posse da ação praticada por outrem e ganham uma experiência a mais em suas vidas.

Levando isso em consideração, neste artigo, os objetivos se voltam para a elaboração de propostas metodológicas que visem a aplicabilidade de uma pedagogia materialista histórico-crítica no âmbito das aulas de Língua Portuguesa e coloque em destaque elementos e categorias estruturais que compõem o texto narrativo. Entre os teóricos da ciência da narratologia que auxiliarão as discussões aqui presentes estão Labov (1997), Barthes (1976), Barros (2005), Fiorin (2008). A ênfase recai sobre questionamentos e atividades cujo desenvolvimento objetiva o trabalho pedagógico no Ensino Fundamental II principalmente, porém nada impede que sejam aplicados em outras séries com as alterações necessárias. Tendo como motivação atividades lúdicas e prazerosas, os textos escolhidos, para análise e desenvolvimento da sequência didática, foram A festa no céu (2019), conto tradicional do Brasil narrado por Luís Câmara Cascudo e A raposa e as uvas (1848), uma das fábulas de Esopo. Obviamente que são diversos os entraves à consecução satisfatória da atividade pedagógica sobre o ensino de narrativas. Logo, este estudo pretende apontar como superar alguns deles a partir do trabalho com textos narrativos da América Latina, repercutindo as vozes de uma pedagogia voltada à humanização, ao pensamento crítico e à reflexão acerca da realidade que nos cerca.

\section{BURLAR O IMPOSSÍVEL, NARRATOLOGIA E ASPECTOS TEÓRICOS}

\footnotetext{
${ }^{7}$ Alphonse de Lamartine “ L'Homme” CEuvrescomplètes de Lamartine, Chez l'auteur, 1860, 1 (p. 77-86). file:///C:/Users/valdeci.oliveira/Downloads/\%C5\%92uvres_compl\%C3\%A8tes_de_Lamartine_(1860)_Tome_1_ L\%E2\%80\%99Homme.pdf)

${ }^{8}$ Bornédanssanature, infinidanssesvœux,

L'homme est undieutombéqui se souvientdescieux.

Soit que, déshérité de sonantiquegloire,

De sesdestinsperdusilgardelamémoire;

Soit que de sesdésirsl'immenseprofondeur

Lui présage de loinsa future grandeur,

Imparfaitoudéchu, l'hommeest le grand mystère.
} 
Tentar burlar a incapacidade própria ou o impossível, eis um motor que move os corações humanos e que os leva à descoberta, à emancipação e ao progresso em diversos sentidos. Tal é o que impulsiona o alfaiate Franz Reichelt, como mostra as imagens abaixo, a aventurar-se da Torre Eiffel, a 04 de fevereiro de 1912, com uma roupa que acreditava fazê-lo capaz de voar, cumprindo queda livre até seu trágico desfecho.

A necessidade de irmos além do que a vida nos possibilita, ou seu revestimento em face de possibilidades ainda não concretizadas, acompanha o ser humano desde a priscas eras. Basta olhar os desenhos encontrados em cavernas para vermos neles acenos de narrativas, mediante representações abstratas, ou interpretações artísticas referentes ao sonho de dilatar o vivido em registros de imagens que permanecem no tempo e nas memórias. Assim, ao dilatar $\mathrm{o}$ vivido no ato de narrar ressignificamos nosso passado, damos sentido ao nosso presente e protejamos o nosso futuro, voltando-nos para nós mesmos e para a nossa trajetória no mundo.

Ao discorrer sobre tragédia, Aristóteles (1998) fala em "entrecho", como "mythos", "trama", "enredo", "conflito" "entrecho" no sentido de composição das ações dos elementos participantes da narrativa trágica, mas que podem ser estendidos a toda tipologia narrativa como uma forma de composição e de articulação dos elementos participantes que compõem o desenrolar da ação narrativa, tais como: sujeito do desejo; objeto do desejo; ágon; protagonista e antagonista; peripécias; tempo; espaço; personagens secundários; narrador e focalizador; clímax, desfecho/desenlace que entram na composição da ação, conforme Aristóteles, e são necessários à consecução do discurso narrativo. Alargando as proposições de Aristóteles, Barros (2005) afirma que as narrativas contêm uma sintaxe própria: "a sintaxe narrativa deve ser pensada como um espetáculo que simula o fazer do homem que transforma o mundo" (BARROS, 2005, p. 20). Para que o ouvinte ou leitor possa atribuir sentidos a esse espetáculo e, por meio desses sentidos, construa um avatar na sua mente, encenando-o, é preciso descrevê-lo e essa descrição deve ir para além de determinar seus participantes e o papel que eles representam. Barros fala em duas concepções de narrativa que se complementam.

\footnotetext{
Narrativa como mudança de estados, operada pelo fazer transformador de um sujeito que age no e sobre o mundo em busca de valores investidos nos objetos; narrativa como sucessão de estabelecimentos e de rupturas de contratos entre um destinador e um destinatário, de que decorrem a comunicação e os conflitos entre sujeitos e a circulação de objetos (BARROS, 2005, p. 20).
}

Vemos então que no discurso narrativo há uma busca em torno do objeto, de modo que o sujeito do desejo direciona seu olhar movido pela procura de um valor e nessa procura ele revela os contratos que estabeleceu ou com que rompeu ao interagir com os outros que vivem a vida social em comum. Segundo Barthes (1976),

"[...] inumeráveis são as narrativas do mundo. Há em primeiro lugar uma variedade
prodigiosa de gêneros, distribuídos entre substâncias diferentes como se toda
matéria fosse boa para que o homem lhe confiasse suas narrativas: a narrativa pode
ser sustentada pela linguagem articulada, oral ou escrita, pela imagem fixa ou
móvel, pelo gesto ou pela mistura ordenada de todas estas substancias; está presente
no mito, na lenda, na fabula, no conto, na novela, na epopeia, na história, na
tragédia, no drama, na comédia, na pantomima, na pintura, no vitral, no cinema, nas
histórias em quadrinhos [...]. Além disto, sob estas formas quase infinitas, a
narrativa está presente em todos os tempos, em todos os lugares, em todas as
sociedades; a narrativa começa com a própria história da humanidade; não há em
parte algum povo algum sem narrativa; todas as classes, todos os grupos têm suas
narrativas" (BARTHES, 1976, p.19-20).

E Barthes continua dando destaque à narrativa quando afirma. 


\begin{abstract}
...a narrativa está presente em todos os tempos, em todos os lugares, em todas as sociedades; a narrativa começa com a própria história da humanidade; não há, nunca houve em lugar nenhum povo algum sem narrativa; todas as classes, todos os grupos humanos têm as suas narrativas, muitas vezes essas narrativas são apreciadas em comum por homens de culturas diferentes, até mesmo opostas: a narrativa zomba da boa e da má literatura: internacional, trans-histórica, transcultural, a narrativa está sempre presente, como a vida (BARTHES, 1976, p. 103-104).
\end{abstract}

Mas se narrativa é tudo isso - e muito mais que isso - há que se ter sempre o cuidado para que, na escola, o trabalho com ela não se torne uma atividade enfadonha, sem graça, sem vida, distante do aluno, já que constitui um gênero discursivo essencial a ser trabalhado em âmbito escolar, especialmente no Ensino Fundamental. Se aos professores de Língua Portuguesa do Ensino Fundamental I e II cabe parte da tarefa de ensinar os alunos a contar, a ler e a escrever textos narrativos, é, pois, necessário zelar para que essa atividade não se esvazie de sentidos.

Assim, ao começarmos a apresentação das propostas metodológicas, é importante nos lembrarmos de que, conforme Labov (1997), não há narrativa sem reportabilidade, ou seja, é próprio do discurso narrativo, do ato de narrar alguma ação ou alguma situação à remissão direta a uma reportagem, no sentido de que o narrar traz inevitavelmente para a cena um acontecimento que merece ser contado porque foge do habitual. Há inúmeros fatos que não são contados por que são por demais comezinhos, ou porque eles não encontraram um narrador que notasse neles algum grau de reportabilidade. E o que é digno de reportagem para os humanos? Tudo aquilo que envolve luta, conflito, demanda, necessidade, carência. Isso porque nas narrativas é que sentimos viver a passagem do tempo, o antes e o depois, a partir da estaticidade da situação inicial, em que o protagonista, como sujeito do desejo, apresenta o seu objeto do desejo, que se constitui numa demanda/necessidade/carência; ou seja, aquilo que falta para se ser o que se quer ser ou aquilo que se precisa para tornar-se ou para continuar a ser o que se é. E, a partir desse ponto estático, dá-se início ao movimento, à dinamicidade do ir-se buscar o que falta. Literalmente, do grego, o termo protagonista quer dizer "aquele que carrega o seu ágon (luta/conflito/jogo). Logo, para entrar em conjunção com o objeto do seu desejo - que pode ser, por exemplo, uma sombra, ou um copo de água para alguém morrendo escaldado e sedento num deserto - o protagonista precisa ir à luta. Nesse sentido, se fosse o caso de alguém estar com sede e dispor imediatamente de um copo d'água para tomar, não teríamos narrativa, e sim um simples relato, porque não há conflito, luta, ágon; enfim, reportabilidade.

De tal forma, a narrativa intercala estaticidade e dinamicidade. Na situação inicial, temos a estaticidade, a apresentação do contexto, do cenário onde se desenrolará a história, as situações de estado do protagonista e das pessoas que ali atuarão. Para haver movimento/dinamicidade/cinesia, é preciso que o protagonista/sujeito do desejo assuma seu ágon e vá à luta para obter o objeto do desejo com o qual precisa entrar em conjunção para superar sua necessidade/carência e ser. Esse movimento rompe a estaticidade e instaura a ação responsável por modificar a situação inicial. Geralmente, nas narrativas infanto-juvenis, essa passagem pode vir marcada por uma das diversas conjunções adversativas. Assim se coloca a questão de junção. O protagonista precisa entrar em conjunção, ou seja, comunhão com aquilo de que precisa ou entrar em disjunção, ou seja, se ver livre daquilo que o impede de ser o que ele deseja, pois nem sempre conseguimos aquilo de que precisamos para sermos mais do que somos ou para continuarmos a ser o que somos.

\title{
2 PROPOSTAS DE APLICAÇÃO
}


Iniciamos pelo conto A festa no céu, cuja situação inicial é a de pássaros fazendo grande propaganda e alvoroço porque foram convidados para ir a uma festa que ocorrerá no céu (Figura 1).

Figura 1 - Giz pastel macio sobre papel Canson tamanho A2

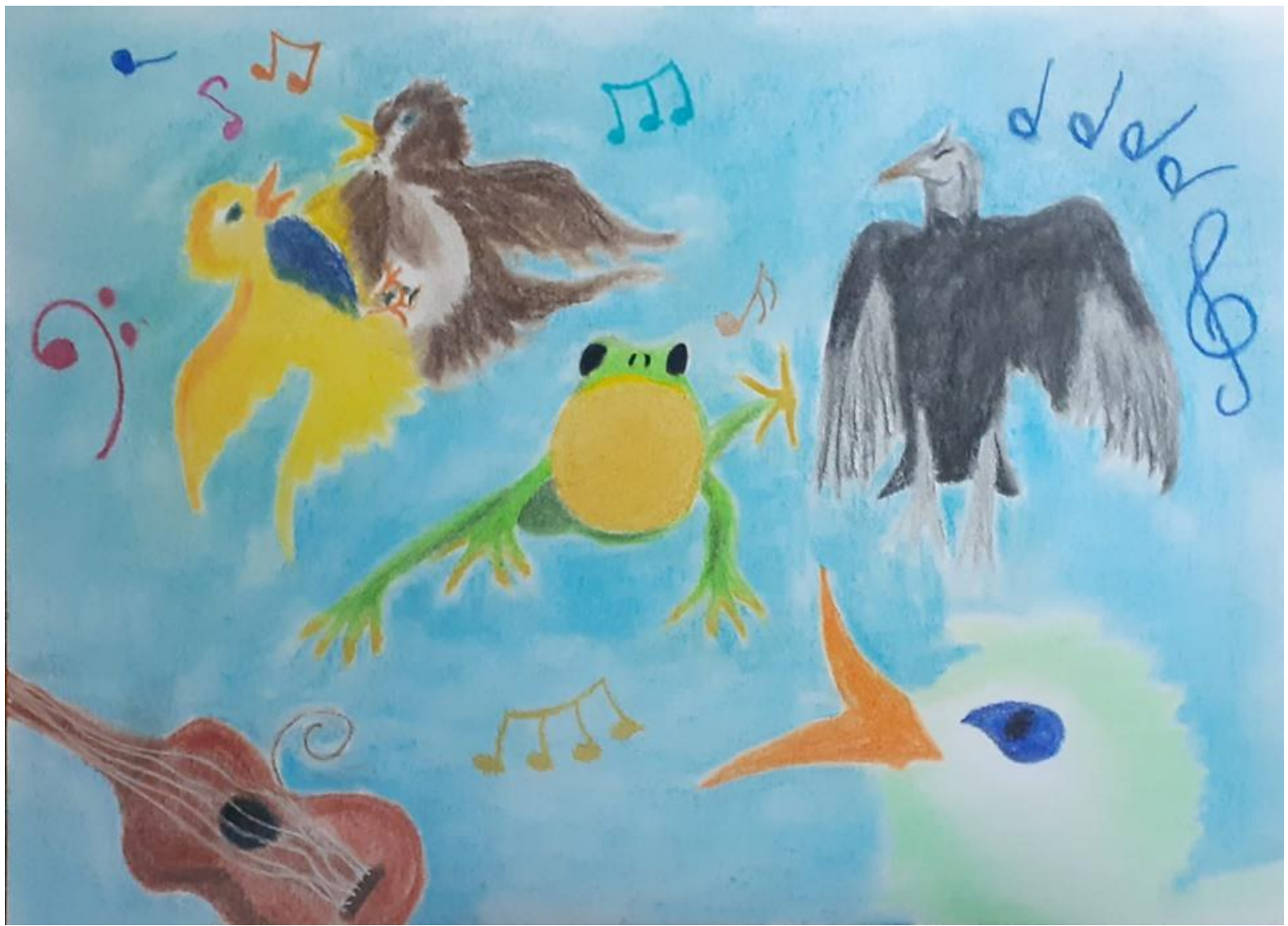

Fonte: Arte criada por André Boniatti.

Entre todas as aves, espalhou-se a notícia de uma festa no Céu.

Todas as aves compareceriam e começaram a fazer inveja aos animais e outros bichos da terra incapazes de voo. Imaginem quem foi dizer que ia também à festa...

O Sapo! Logo ele, pesadão e nem sabendo dar uma carreira, seria capaz de aparecer naquelas alturas.

Pois o Sapo disse que tinha sido convidado e que ia sem dúvida nenhuma.

Os bichos só faltaram morrer de rir. Os pássaros, então, nem se fala!

O Sapo tinha seu plano. Na véspera, procurou o Urubu e deu uma prosa boa, divertindo muito o dono da casa. Depois disse:

- Bem, camarada Urubu, quem é coxo parte cedo e eu vou indo, porque o caminho é comprido. O Urubu respondeu:

- Você vai mesmo?

- Se vou? Até lá, sem falta!

Em vez de sair, o Sapo deu uma volta, entrou na camarinha do Urubu e, vendo a viola em cima da cama, meteu-se dentro, encolhendo-se todo.

O Urubu, mais tarde, pegou na viola, amarrou-a a tiracolo e bateu asas para o céu, rru-rru-rru...

Chegando ao céu, o Urubu arriou a viola num canto e foi procurar as outras aves.

O Sapo botou um olho de fora e, vendo que estava sozinho, deu um pulo e ganhou a rua, todo satisfeito.

Nem queiram saber o espanto que as aves tiveram, vendo o Sapo pulando no céu!

Perguntaram, perguntaram, mas o Sapo só fazia conversa mole. 
A festa começou e o Sapo tomou parte de grande.

Pela madrugada, sabendo que só podia voltar do mesmo jeito da vinda, mestre Sapo foi-se esgueirando e correu para onde o Urubu se havia hospedado.

Procurou a viola e acomodou-se, como da outra feita.

O sol saindo, acabou-se a festa e os convidados foram voando, cada um no seu destino.

O Urubu agarrou a viola e tocou-se para a Terra, rru-rru-rru...

Ia pelo meio do caminho, quando, numa curva, o Sapo mexeu-se e o Urubu, espiando para dentro do instrumento, viu o bicho lá no escuro, todo curvado, feito uma bola.

- Ah! camarada Sapo! É assim que você vai à festa no Céu? Deixe de ser confiado...! E, naquelas lonjuras, emborcou a viola. O Sapo despencou-se para baixo que vinha zunindo. E dizia, na queda:

- Béu-Béu! Se desta eu escapar, nunca mais bodas no céu!...

E vendo as serras lá embaixo:

- Arreda pedra, senão eu te rebento!

Bateu em cima das pedras como um genipapo, espapaçando-se todo. Ficou em pedaços.

Nossa Senhora, com pena do Sapo, juntou todos os pedaços e o Sapo voltou à vida de novo.

Por isso o Sapo tem o couro todo cheio de remendos (CASCUDO, 2019, n.p). ${ }^{9}$

Como apenas eles (os pássaros) podem voar, a divulgação da festa visa mesmo causar despeito; inveja; ressentimento e indiferença nos bichos que não poderão ir, por não poderem voar. Eis aí um belo exemplar de "tentação do impossível". Mas um sapo "sabido", ao saber da festa no céu, deseja dela participar. Temos aqui na figura do sapo o actante sujeito do desejo e, na festa no céu, o actante objeto do desejo, e, além do mais, no fato de que ele - por ser um sapo - não dispõe do poder de voar, temos o oponente do desejo, ou antagonista, que se opõe à realização do desejo do protagonista o sapo. Assim, o animal tem o querer, mas não tem o saber. E se não tem o saber, não tem o poder; portanto, não pode fazer, nem ser, pois não tem conjunção com aquilo que deseja.

Mas o sapo começa a alardear que também irá à festa no céu. E, como ele era um sapo sabido, sabe encontrar na esperteza uma saída: enganar o urubu, então se esconder no espaço que há dentro da viola é a solução. Com essa estratégia, ele ganha o poder de ir até à festa no céu. Logo, vemos que nessa narrativa, assim como em outras, temos duas forças contrárias: $\mathrm{O}$ protagonista e o antagonista. Numa narrativa, esse embate entre protagonista e antagonista pode ter um round apenas ou diversos rounds, dependendo das forças dos combatentes. Um exemplo bem banal: se for alguém tentando fazer regime, pode ser que a gula vença alguns rounds e a necessidade de emagrecer vença outros. Se a pessoa consegue emagrecer é porque ela venceu seu antagonista que era a gula. Essa luta vale para o etilismo, drogadição e outras dependências das quais o protagonista precisa entrar em disjunção, pois elas se constituem naquilo que o impede de ser. Como se nele mesmo morassem o protagonista e o antagonista, abraçados na luta perpetua que Sá de Miranda efabulou no belíssimo poema narrativo, chamado "Comigo me desavim"10. Do embate entre essas forças sairá um vencedor e um perdedor.

9 CASCUDO, Luís Câmara. A festa no céu (1848) In: Portal do professor. Acesso em: http://portaldoprofessor.mec.gov.br/fichaTecnicaAula.html?aula=27371. Acesso em: 03 out. 2019.

${ }^{10}$ Cantiga "Comigo me desavim", de Sá de Miranda:

Comigo me desavim,

Sou posto em todo perigo;

Não posso viver comigo

Nem posso fugir de mim.

Com dor da gente fugia,

Antes que esta assicrecesse:

Agora já fugiria 
Entretanto, por que o sapo queria também ir à festa no céu? Podemos interrogar por vários motivos: Sedução? Complexo de inferioridade em relação às aves? Curiosidade e vontade de conhecer o céu? Gulodice, já que em festa há muita comida, o sapo poderia sonhar com encher a barriga de quitutes, matar a fome, interagir, se exibir? No caso do sapo, parece que todos esses motivos são motor da ação. Na verdade, são questões postas à descoberta da interpretação do leitor, algumas implícitas, que ficam abertas até o fim e podem ser preenchidas pela recepção. E aqui está um ponto importante para o trabalho com o texto narrativo em sala de aula, fazer com que o aluno participe desse conflito, compreenda-o com seus olhos, produza texto acerca do que se lhe apresenta aos olhos, e como fazer isso? Levando-o a se colocar no lugar do sapo, ou em situações análogas.

Sobre o período que conclui o parágrafo acima, vale voltarmos a dois aspectos. Barthes (1976) salienta que obra (no caso um texto fonte de discussões, elevado de uma maneira ou outra - pela própria persistência no tempo talvez) é aquela que produz texto. $\mathrm{Ou}$ seja, uma obra literária - agora centremo-nos na literatura - produz discussão, produz resposta, reportabilidade, como em Labov, produz outras obras. Ela repercute, por isso não morre. E o problema em ela ser bem recebida em sala de aula, no caso de nossa preocupação neste artigo, é o de que os alunos possam, ou mais, sintam-se instigados a produzir texto acerca dela. E para isso é necessário que eles sejam capazes de visualizá-la (que ela se apresente aos seus olhos, visual e sensivelmente). Se o texto descreve e narra em face de produzir imagens, ou mesmo de resgatá-las ao passado, é necessário que quem entre em contato com narrativas seja capaz de percebê-las em sua imaginação, ou não haverá compreensão, muito menos prazer estético. Para tanto, faz-se necessário que o professor, ao assumir o papel de "ensinar" narrativas, primeiramente goste de lê-las e sinta desejo de compartilhá-las. Pelos olhos do professor, assim, os alunos serão capazes de ver. Ou melhor, não é papel do professor mostrar, mas fazer ver. Como? Lendo antes diversas vezes, até conseguir dar a entonação necessária à história. Muita gente lê tão sem graça, como se fosse um "ford velho" numa subida monótona e enfadonha. Leitura é vida e ela começa pelos professores. Os professores devem primeiro eles mesmos lerem em voz alta as histórias para os alunos. Uma, duas, três vezes ou mais. Ler contando com entusiasmo, compreensão e entonação. Gesticulando e, se possível, imitando vozes, convidando a imitar - os alunos animais, a participar da festa. Apenas com visada lúdica, de uma maneira lúdica. $\mathrm{Na}$ brincadeira se pode fazer muita coisa séria. As propostas feitas aqui estarão mortas, sem essa leitura engajada do professor. Na sequência das atividades, os alunos começam a ler diversas vezes em silêncio e em voz alta.

Depois que os alunos se apoderaram da narrativa, seria muito bom ativar a imaginação (recurso mnemônico) dos alunos para a plasticidade da imagem, propondo a criação de cartazes, recontagem em quadrinhos, pôsteres, desenhos diversos. Evitando, algumas vezes, de mostrar-lhes ilustrações, para ativarem a capacidade de eles mesmos representarem as histórias, cenários e personagens. Perceba-se que algumas histórias estão abertas à diversidade. Por exemplo, qual a cor ou a espécie dos pássaros (afora o que esteja indicado no texto)? De que espécime de sapo se está falando? O próprio instrumento musical, como é ele? Depende do espaço geográfico e cultural em que a criança, ou adulto, vive, esta fará suas escolhas (pré-determinadas, contudo). Por isso é que se faz necessário também deixar com que os alunos pensem por si, narrem suas próprias histórias da vida cotidiana, porque é assim que passará a compreender a narrativa como um processo estético e próprio da diversidade.

De mim, se de mim pudesse.

Que meo espero ou que fim

Do vão trabalho que sigo,

Pois que trago a mim comigo

Tamanho imigo de mim? 
Assim, no esforço de eles mesmos contarem e, subsequentemente, no esforço em ouvir o outro contar, compreenderão o processo inato de decodificação da narrativa em imagens, próprio da condição e capacidade humanas, a partir do interesse sobre o outro e da tentativa de fazer-se entender.

Vemos então que o texto narrativo, após decodificado, suscita muitas reflexões. A primeira foi acima exposta e, claro, pode ser proposta ao debate pelo próprio professor, que não limitará as respostas, a não ser ao nível da verossimilhança necessário ao entrecho. $\mathrm{E}$ poderíamos ainda perguntar: Por que os outros animais riram do sapo? Esse sapo era um sapo metido e gabola? Ou ele gostava de festa e essa festa tivera muita divulgação? Você já riu de alguém que não pode fazer alguma coisa, embora quisesse? E você: já quis fazer alguma coisa e não pode? Como essas questões entramos na vida, no querer dos alunos e os ajudamos a perceber quantas vezes foram sapos querendo ir às festas no céu. Conseguiram? Não conseguiram? Por quê? O que ganharam e o que perderam nesse querer? Ou apenas quiseram, sonharam e ficaram querendo, sem pensar em modos de efetivar, de lutar para realizar seus desejos? E se quisermos ir além: que sentimentos resultam dessa ação de querer, mas não empreender luta para se tomar posse do que se quer? É possível para algum ser humano realizar todos os seus desejos e tomar posse de tudo que se quer?

É claro que a interação do professor com os alunos deve esquivar-se ao máximo de inculcar nestes os seus valores morais. $O$ texto não serve à moralidade, senão para pôr a mesma em debate, para suscitar reflexões subjetivas. Os alunos devem ser livres para pensar, sempre em face da verossimilhança e da coerência, elementos a serem questionados pelo professor. Contudo, conduzir a uma interpretação única porque nela se crê é vezo indefensável. Deve ser levado em conta o capital cultural do aluno, quais são seus conhecimentos de mundo. Lembremos de que o texto não pode ser pretexto para uma didática moral, ou moralizante. É por tal motivo que, antes de qualquer questionamento, o aluno deve ser conduzido a fruir a diversão que o texto propõe, o prazer do ouvir, do ler, do conhecer, o prazer plástico do ver e do sentir e de viver a experiência de outrem como se lhe fosse própria. Depois, deve ser orientado a buscar dentro de si e de sua realidade uma interpretação para os problemas suscitados pelo ágon_vivido pelo sapo. Pôr em debate a interpretação entre pares de idade e escolaridade similar é frutificante, mas impor conceitos por preceitos nossos seria o mesmo que destruir a fruição do texto para esse aluno, que perderá o desejo de ler a obra, pois foi incapaz de produzir, a partir dela, um texto.

Depois, mesmo interdisciplinarmente, podemos propor outras inferências, instigando os discentes a estabelecer relações e a desenvolver novos conteúdos: se não tem o poder para voar, como o sapo encontra a saída? Faz uso de um saber, esperteza, técnica, ou de uma prótese (a viola e as asas do urubu) para chegar até os céus? Nós humanos também não voamos, iguais ao sapo? O que fizemos para voar? Porque sentimos inveja mesmo de um pequeno pardalzinho, por ser ele capaz de voar? Imagine-se, antes do avião, quantas pessoas sonharam voar. Quais os custos da realização desse sonho?

Podemos avançar ainda aos campos da pesquisa: como ir para os céus já foi muito perigoso, é possível propor pesquisar, por exemplo, o que acontecia com os aviadores quando os aviões não tinham cabine pressurizada? Ou se os discentes conhecem a história da cachorra russa Laika, que foi para o céu numa espaçonave? Lançando para a ordem pessoal, as questões podem percorrem o seguinte caminho: como você faz para conseguir alguma coisa que quer e não pode? Desiste e faz como a raposa da fábula A raposa e as uvas, que será apresentada na sequência? Não desiste e enfrenta os maiores obstáculos para conseguir o que quer? Mas e se o que você quer estiver muito além das suas forças de atuação no mundo?

Em A raposa e as uvas, o ágon resolve-se, diversamente de n'A festa do céu, por meio da desistência, visto a incapacidade (o não saber) que a raposa demonstra em persistir no problema. A fábula, escrita por Esopo, é a seguinte (Figura 2): 
Figura 2 - Giz pastel seco e lápis de cor aquarelável sobre papel Canson tamanho A4

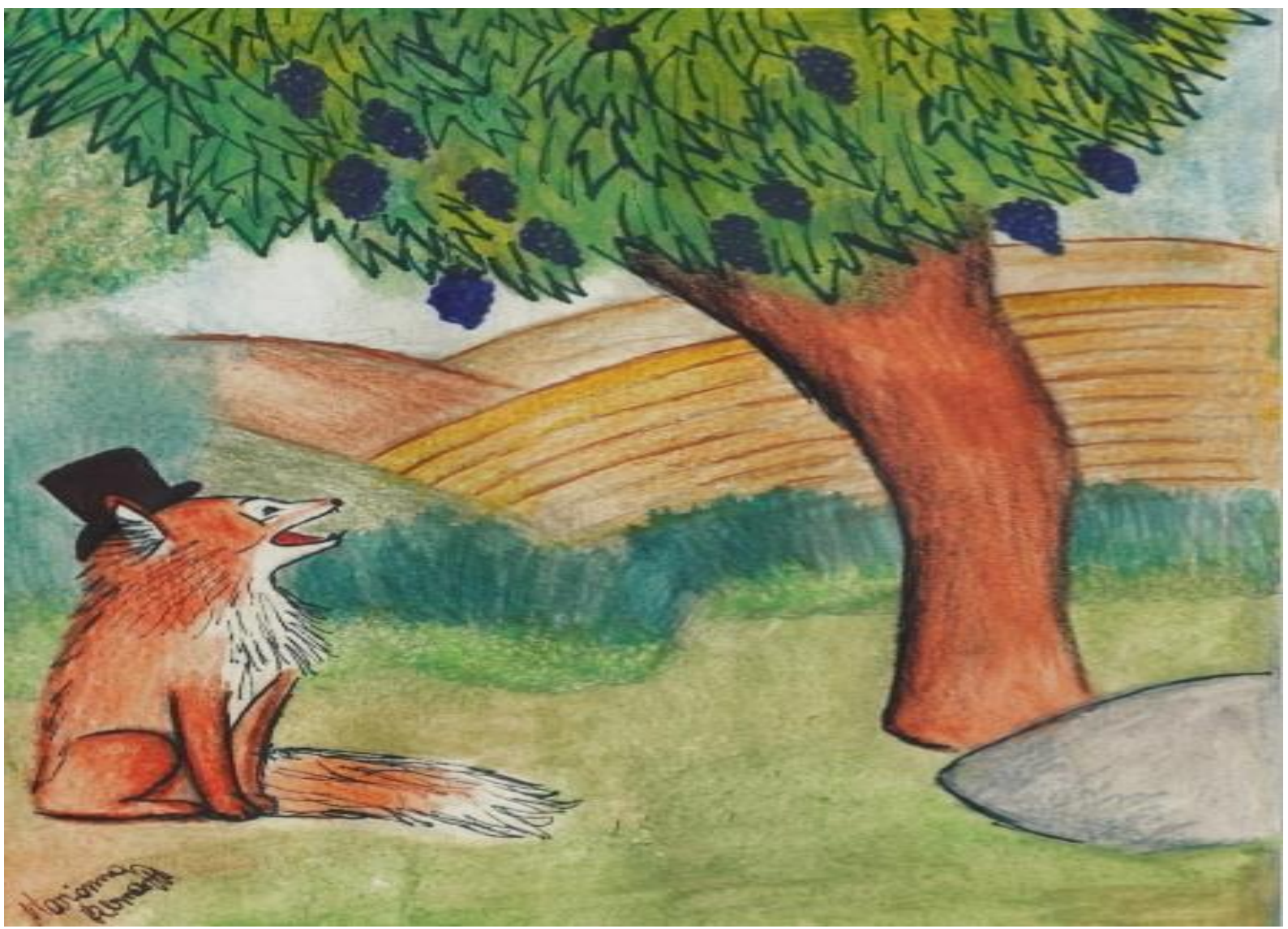

Fonte: Arte criada por Marianna Bernartt.

Uma Raposa, aproximando-se de uma parreira, viu que ela estava carregada de uvas maduras e apetitosas. Com água na boca, desejou-as comer e, para tanto, começou a fazer esforços para subir até elas. Porém, como estivessem as uvas muito altas e fosse muito difícil a subida, a Raposa tentou mas não conseguiu alcançá-las. Disse então:

- Estas uvas estão muito azedas e podem desbotar os meus dentes; não quero colhêlas agora porque não gosto de uvas que não estão maduras.

E dito isso, se foi (ESOPO, 1848, n.p). ${ }^{11}$

A desculpa que a raposa encontra, como que para convencer-se a si mesma, é demonstrativo de pessoas que pouco se dedicam, preguiçosas ou desleixadas, que preferem as coisas fáceis e desistem sem hesitar do que possa exigir delas um tempo maior de dedicação. Sua recusa às uvas encontra-se com a recusa dos seres humanos em aprender, aprimorar suas capacidades mediante a reflexão e o teste, a aplicação. É uma boa deixa para preocuparmonos, junto aos discentes, em refletir sobre a prática dos próprios alunos.

No âmbito do plano didático em sala de aula, hoje não há mais a hesitação em entendermos a aprendizagem - e todo o seu processo - como um projeto espiralado. Quando pensamos em PPCs e planos docentes, temos de levar em conta que os conteúdos não se resolvem por si, isoladamente. Eles formam um conjunto. E se é método pedagógico pensar a interdisciplinaridade (como apontado nos questionamentos acima, na análise de A festa do

${ }^{11}$ As Fábulas de Esopo. Adaptação: Joseph Shafan Baseado na edição em língua portuguesa: "Fabulas de Esopo - com aplicações moraes a cada fabula" - 1848 - Paris, Typographia de Pillet Fils Ainé.http://www.dominiopublico.gov.br/download/texto/ea000378.pdf. 
céu, questionando-se elementos exofóricos, implícitos no texto, que adjungem a outros campos de conhecimento), é de suma relevância ainda atentarmo-nos para o fato de que o conteúdo proposto em currículo deve ser inter-relacional. Ou seja, não trabalhamos com elementos indispostos uns em relação aos outros, mas com quebra-cabeças, que, quando bem dispostas as peças, complementam-se de maneira acessível e facilitadora para o aprendizado. Por isso, criou-se a noção de sequência didática.

A sequência didática pressupõe em si a aquisição de conteúdo como um movimento em espiral, em idas e voltas. O problema da escola, explícito em seu sistema e incompreendido pelos, ou mal explicado aos, docentes, em grande monta, está em se querer resolver os conteúdos como se fossem momentos distintos da aprendizagem, separados em caixas, empacotados, cozidos, servidos e lançados ao léu logo após, como exigência de um sistema burocrático em que conta conteúdo ensinado, não assimilado. Os conteúdos devem, no entanto, circular pela sala de aula durante os anos, em idas e voltas. É óbvio que devem ser elencados conforme a maturidade dos alunos, mas seu avanço deve ser previsto em sequências de acréscimo. É como se as sementes fossem lançadas já mediante a previsão do tratamento das plantas em face da colheita, ou da finalidade máxima: o domínio do saber.

Nesse sentido, o conto A festa do céu pode apresentar-se como ponto de partida para uma sequência didática que agora suscitasse o gênero fábula em A raposa e as uvas, ou viceversa. Em comparação, nós temos ágones que clamam o "desejo do impossível”, entretanto com resoluções, ou desfechos, bastante diferentes. Qual das duas personagens, o sapo e a raposa, agiu com maior sabedoria?

Lembrando-se que na estrutura da fábula temos um elemento primordial, que é a sanção, ou a moral da história, é interessante refletir-se qual essa moral? O que o autor, em sua época, queria aludir com essa história? Vejamos que, em relação ao conto de Luís Câmara Cascudo, há elementos dissonantes, já que se trata de conto. O final, por exemplo, em que se insere um fundo de religiosidade, trazendo o aspecto do maravilhoso à narrativa, faz com que nos sosseguemos e enchamos os olhos de amor pelo sapinho, que, por fim, mereceu a bênção dos céus. Já na fábula, por pressupor um eixo didático-moral, o final abre ao leitor uma reflexão interior, que não se resolve no maravilhoso, contudo em sua própria existência, em seu dia a dia. Logo, na fábula, tal elemento conclusivo é ponto-chave à exploração em sala de aula. E uma forma de provocar nos discentes do ensino fundamental o vislumbre desse propósito, deixando-lhes a cargo sua interpretação, é o trabalho com o teatro.

O teatro é essencial à vida humana, tanto quanto a narrativa, pois é uma forma de imitar com o próprio corpo, os gestos, a fala, a ação das personagens, a narração. Aristóteles (1998) enfatiza o quanto a dramaturgia volta-se à ação, aquela que organiza os caracteres, as personagens e seus modos de agir, atuar. Observemos que a palavra atuar refere-se à raiz ato,

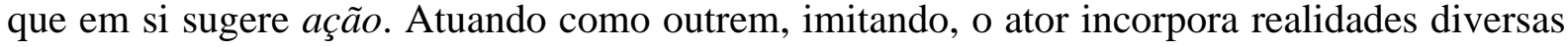
compreendendo-se compassivamente com elas, mesmo que em âmbito de jogo, de brincadeira, lúdico. A proposta não é desenvolver cenários e figurinos, mas que as crianças possam incorporar personalidades diversas das delas; assim, mesmo que inocentes disso, discutindo as atitudes dessas personagens, comparando-as com as suas próprias.

Contudo, pairarmos na imitação como simples fator didático de apreensão moral. Já discutimos isso, não é propósito do ensino de gêneros literários ou discursivos, nem de nenhum conteúdo disciplinar escolar. Logo, trazemos à tona uma expansão desse ato didáticoteatrológico a partir de dois de entre os vários e excelentes exercícios propostos por Augusto Boal, um contido em sua obra Teatro do oprimido e outras poéticas políticas (2013) e o outro em Jogos para atores e não atores (2012). Boal expande as técnicas de Bertold Brecht ${ }^{12}$

\footnotetext{
${ }^{12}$ Um dos escritores fundamentais deste século: revolucionou a teoria e a prática da dramaturgia e da encenação, mudou completamente a função e o sentido social do teatro, usando-o como arma de conscientização e politização in https://portaldosatores.com/2017/08/14/vida-e-obra-bertolt-brecht/
} 
numa acepção centrada na realidade latino-americana, o que o faz teatrólogo de suma importância em todo o mundo. Seus exercícios propõem a ressignificação dos valores vivenciados no cotidiano concreto de pessoas comuns. Ao lecionar sobre o Teatro do Oprimido $^{13}$, no uso do teatro enquanto discurso, ele propõe um exercício a que intitula "dramaturgia simultânea", que consiste no seguinte, em suas próprias palavras:

\begin{abstract}
A cena deve ser representada até o ponto em que se apresente o problema central, que necessite uma solução. Neste ponto, os atores param de interpretar e pedem ao público que ofereçam soluções possíveis, para que as interpretem, para que as analisem. Em seguida, improvisando, interpretam todas as soluções propostas, pelo público, uma a uma, sendo que todos os espectadores têm o direito de intervir, corrigindo ações ou falas inventadas pelos atores, que são obrigados a retroceder e a interpretar outra vez as mesmas cenas ou dizer as novas palavras propostas pelos espectadores. (BOAL, 2013, p. 136).
\end{abstract}

Tal exercício em relação à fábula - embora em sala de aula pudesse limitar o número de representações, talvez buscando uma apenas em que o grupo de espectadores acordasse faria com que os discentes pudessem a mais que julgar a atitude da raposa, empenhar-se em outra atitude para sentirem-se dentro do problema e solucioná-lo. Em relação à fábula $A$ raposa e as uvas, o ponto em que se apresenta o problema é justamente o ponto em que a raposa resolve desistir, ao tentar e não alcançar. Nesse momento, a turma seria convidada a discutir soluções analisando sempre a coerência destas. Por exemplo, alguém pudera supor pegar uma escada. Contudo, a raposa seria capaz? Que verossimilhança no entrecho poderia fazer isso possível? Ela está próxima a uma escada, ou a um local em que haja uma escada? Ao fim, as melhores soluções seriam improvisadas. Conquanto em meio à representação improvisada, mediante a ação, pudessem ser vislumbrados novos problemas, não refletidos ou mentalizados pelos alunos anteriormente ao ato. Por isso a importância em representar, visualizar ações, atitudes, reações que fazem parte do caráter de cada um.

O Teatro Fórum é outra alternativa que põe em debate o caráter das personagens e a resolução de problemas. Nesse exercício, monta-se um fórum em sala, para julgar o enredo e apontar as falhas de caráter nas atitudes e falas das personagens. Assim, propõe-se também a ressignificação e a improvisação de um novo enredo a partir do debate. Ambos valiosos exercícios sem grande complexidade, desde que o professor entenda que tudo deve dar-se em forma de brincadeira séria, de processo de reorganização moral em discussão, de reflexão e jogo, de ludo. Materialismo histórico-dialético em prática.

\title{
3 CONSIDERAÇÕES FINAIS
}

Os professores e os pais sabem que a vida humana é insegura e que não nos oferece nenhuma garantia e, talvez porque já tenhamos enfrentado muitos e muitos obstáculos, queremos aplainar as caminhadas de nossos alunos e filhos. Não estamos errados em fazê-lo, mas como nos lembra Walter Benjamin banimos da vida das crianças, adolescentes e jovens (alunos e filhos) o conhecimento necessário sobre as lutas agônicas que travamos, incluindo

\footnotetext{
${ }^{13}$ Para fazer frente à censura e à repressão desencadeada pelo AI-5, Boal incrementa sua aproximação com as propostas de Bertolt Brecht (1898-1956). Inspirado na peça didática, monta Teatro Jornal, 1971, com o Núcleo 2 do Teatro de Arena. A encenação, aberta ao improviso, utiliza notícias do dia, comentadas pelos atores sob diversos modos. Outros textos também são utilizados para polemizar, extrair contradições e pontos de vista divergentes contidos num mesmo relato. Chega, desse modo, a uma crítica global das formas narrativas tradicionais, exposta no texto $O$ Sistema Trágico Coercitivo de Aristóteles, no qual tece as bases de sua proposta e faz críticas à Poética in https://enciclopedia.itaucultural.org.br/termo616/teatro-do-oprimido.
} 
nesse banimento a visão dos hospitais e da morte ${ }^{14}$. Desse mundo sem óbices, porém, pode resultar a "aversão cada vez maior ao trabalho prolongado".

As duas narrativas aqui trabalhadas são clássicas no sentido de que expressam duas formas diferentes de se lidar com as "tentações do impossível". São chamadas de fábulas, com suas devidas variações, porque os animais que as protagonizam são antropomorfizados para serem exemplos dos obstáculos e lutas que os humanos enfrentam, em prol de serem aquilo que precisam ou que querem ser. Elas figuram saídas e formas de ação, atuação de como os humanos podem lutar e se arranjar na vida social, como se fossem um repositório de banco de dados de lutas/problemas, ágones, e das saídas e resoluções encontradas como meios de ultrapassá-los para realizar sua vocação ontológica: a de manter a vida e de estendê-la um pouquinho mais.

\section{REFERÊNCIAS}

ALBERTI, Verena. Narrativas na história oral. Anais do Simpósio Nacional de História João Pessoa: ANPUH-PB, s/p. 2003.

ARISTÓTELES. Poética. Tradução e comentários de Eudoro de Souza. Brasília: Imprensa Nacional/ Casa da Moeda, 1998.

BARROS, Diana Luz de. Teoria semiótica do texto. 4. ed. São Paulo: Editora Parma, 2005.

BARTHES, Roland. A análise estrutural da narrativa. Seleção de ensaios da revista Communications. Rio de Janeiro: Editora Vozes Ltda.1976.

BARTHES, Roland. Da obra ao texto. In: O rumor da língua. Trad. Mário Laranjeira. $2^{\mathrm{a}}$ ed. São Paulo: Martins Fontes, 1976.

BENJAMIN, Walter. “O Narrador: considerações sobre a obra de Nikolai Leskov”. In: Magia e técnica, arte e política: ensaios sobre literatura e história da cultura. São Paulo: Brasiliense, 1994, p. 197-221.

\footnotetext{
14 "No decorrer dos últimos séculos, observamos que a ideia da morte vem perdendo, na consciência coletiva, sua onipresença e sua força de evocação. Esse processo se acelera em suas últimas etapas. Durante o século XIX, a sociedade burguesa produziu, com as instituições higiênicas e sociais, privadas e públicas, um efeito colateral que inconscientemente talvez tivesse sido seu objetivo principal: permitir aos homens evitarem o espetáculo da morte. Morrer era antes um episódio público na vida do indivíduo, e seu caráter era altamente exemplar: recordem-se as imagens da Idade Média, nas quais o leito de morte se transforma num trono em direção ao qual se precipita o povo, através das portas escancaradas. Hoje, a morte é cada vez mais expulsa do universo dos vivos. Antes não havia uma só casa e quase nenhum quarto em que não tivesse morrido alguém. (A Idade Média conhecia a contrapartida espacial daquele sentimento temporal expresso num relógio solar de Ibiza: ultima multis). Hoje, os burgueses vivem em espaços depurados de qualquer morte e, quando chegar sua hora, serão depositados por seus herdeiros em sanatórios e hospitais. Ora, é no momento da morte que o saber e a sabedoria do homem e, sobretudo sua existência vivida - e é dessa substância que são feitas as histórias - assumem pela primeira vez uma forma transmissível. Assim como no interior do agonizante desfilam inúmeras imagens visões de si mesmo, nas quais ele se havia encontrado sem se dar conta disso -, assim o inesquecível aflora de repente em seus gestos e olhares, conferindo a tudo o que lhe diz respeito aquela autoridade que mesmo um pobre-diabo possui ao morrer, para os vivos em seu redor. Na origem da narrativa está essa autoridade. A morte é a sanção de tudo o que o narrador pode contar. É da morte que ele deriva sua autoridade. Em outras palavras: suas histórias remetem à história natural". BENJAMIN, Walter. "O Narrador: considerações sobre a obra de Nikolai Leskov". In: Magia e técnica, arte e política: ensaios sobre literatura e história da cultura. São Paulo: Brasiliense, 1994, p. 197-221.
} 
BOAL, Augusto. Jogos para atores e não atores. Rio de Janeiro: Civilização Brasileira, 2012.

BOAL, Augusto. Teatro do oprimido e outras poéticas políticas. São Paulo: Cosac Naify, 2013.

CASCUDO, Luís Câmara. A festa no céu (1848) In: Portal do professor. Disponível em: http://portaldoprofessor.mec.gov.br/fichaTecnicaAula.html?aula=27371. Acesso em: 03 out. 2019.

CASCUDO, Luís da Câmara. Contos tradicionais do Brasil. Col. Joaquim Nabuco. Ediouro, 2019.

ESOPO. As Fábulas de Esopo Adaptação: Joseph Shafan Baseado na edição em língua portuguesa: "Fabulas de Esopo - com aplicações morais a cada fabula", 1848.

FIORIN, José Luiz. As Astúcias da Enunciação: as categorias de pessoa, espaço e tempo. $2^{\text {a }}$ ed. São Paulo: Editora Ática S.A., 2008.

LABOV, William. Some Further Steps in Narrative Analysis. In: Bamberg, M. (ed.). Oral versions of personal experience. Three decades of narrative analysis. A special issue of The Journal of Narrative and Life History, 1997.

LAMARTINE, Alphonse de. "L'Homme” Euvrescomplètes de Lamartine, Chez l'auteur, 1860, 1 (p. 77-86).

file://C:/Users/valdeci.oliveira/Downloads/\%C5\%92uvres_compl\%C3\%A8tes_de_Lamartine _(1860)_Tome_1_L\%E2\%80\%99Homme.pdf)

LLOSA, Mario Vargas. A tentação do impossível: Victor Hugo e Os miseráveis. Tradução Paulina Wacht e Ari Roitman. Rio de Janeiro: Objetiva, 2012.

MAIAKOVSKI, Vladímir. Maiakovski. Antologia Poética. Trad. E. Carrera Guerra. Max Limonad, 1956.

MIRANDA, Sá de. Poesias escolhidas: introdução, seleção e crítica de José V. de Pina Martins. Lisboa: Verbo, 1969.

PESSOA, Fernando. Impermanence. In: Arquivo Pessoa. Disponível em: http://arquivopessoa.net/textos/3582. Acesso em: 03 out. 2019. 